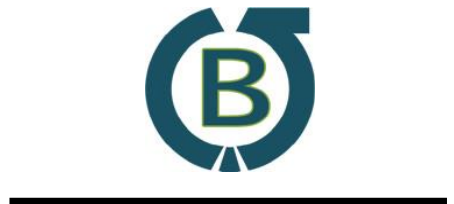

FACULTY OF MANAGEMENT \& FINANCE UNIVERSITY OF COLOMBO
Colombo Business Journal

INTERNATIONAL JOURNAL OF

THEORY \& PRACTICE

Vol. 08, No. 01, June, 2017

\title{
Illiquidity Based Factor Construction in Asset Pricing: An Analysis on Long Run Performance of Sri Lankan Initial Public Offering Stocks
}

\author{
T.C Ediriwickrama ${ }^{a 1}$, A.A Azeez ${ }^{\mathrm{a}}$ \\ ${ }^{a}$ Department of Finance, University of Colombo, Sri Lanka
}

\begin{abstract}
IPO long run underperformance is a widely debated anomaly in corporate finance literature. Present study inquires whether above anomaly exists even after pricing for well known risk factors constructed based on size as well as illiquidity. This study proposed a new illiquidity based four factor asset pricing model and tested it using Sri Lankan initial public offering (IPO) stocks in inter war period and post war period. Proposed model was compared with Carhart (1997) four factor model. Both ordinary least square regression and weighted least square regression have been used to test Carhart's model and proposed model in Sri Lankan context. It is found that long run IPO underperformance anomaly existed even after pricing for the illiquidity premium. Further two models perform very similarly and it is not fair to say one is superior to the other.
\end{abstract}

Keywords: Illiquidity, IPO, Colombo Stock Exchange (CSE), Sri Lanka

\section{Introduction}

Capital market plays an important role in the modern economy of any country hence the economic development of the country. However, performance of the Sri Lankan equity market depended on number of macroeconomic factors including the ethnic conflict which existed in the island from the beginning of 1980's. However armed conflict was over in May 2009, but sustainable solutions towards peace was yet to be implemented at the top level of political leadership as well as at grass root levels according to Schulz and Peiris (2010). Pagano (1993); Levine and Zervos (1996) found a positive relationship between economic growth and stock 
market performance as well as development. Dayaratne (2014) empirically revealed that peace is an essential component for smooth performance of Sri Lankan stock market. Sri Lanka's equity market was seriously affected due to three decade long ethnic conflict. Both foreign and local investor participation was low during that period. With the end of the armed conflict in May 2009, market indices of Colombo Stock Exchange (CSE) which is Sri Lanka's only equity exchange rose rapidly, creating new records. Sri Lanka's CSE was included in to the 10 best performing stock markets in the world just after the war in 2009. Reasons for this success are strong local investor activity after a long period of war ridden years, increased foreign investors' interest mainly due to financial crisis that existed in most of the developed markets specifically in the years of 2008 and 2009, and rapid infrastructure development in the country via higher government spending. Dayaratne (2014) analysed performance of CSE in inter war and post war periods.

Initial public offering (IPO) which is the first sale of company's shares to general public emerged as the fastest and the easiest mechanism for Sri Lankan corporate entities to gain listing in post conflict era in Sri Lanka. With end of war in May 2009, number of IPOs conducted in Sri Lanka rapidly increased. 9 and 13 IPOs were listed in CSE in 2010 and 2011 respectively, compared to 2 IPOs each in 2008 and 2009. However, number of equity IPOs recorded in recent years are not that high compared to years immediately after the end of the war in 2009. 1, 6 and 2 IPOs were recorded in years 2013, 2014 and 2015 respectively. But on the other hand, amount raised from primary market activities (which includes both equity and debt) exceeded Rs. 80 billion in 2015 compared to Rs.57 billion in 2014. IPO long run stock price underperformance was first documented by Ritter (1991) in American market. Loughran and Ritter (1995) found that firms managed to launch their IPOs in hot market conditions and it is termed as 'windows of opportunity' hypothesis. Sri Lanka's post war period is also similar to a hot market condition. In Sri Lankan context, Peter (2007) found that long run IPO returns in $3^{\text {rd }}$ year after listing were negative which supports to the IPO long run underperformance anomaly. Ediriwickrama and Azeez (2015) used multi factor models and found that Sri Lankan IPO stock portfolios were underperforming in the long run ${ }^{1}$.

\footnotetext{
${ }^{1}$ In Sri Lankan context, Peter (2007) tested IPO long run performance using event study method (more specifically buy and hold abnormal returns). Alternatively Ediriwickrama and Azeez (2015) used calendar time methodology to examine IPO long run anomaly using Fama and French (1993) and Carhart (1997) models. Ediriwickrma and Azeez (2015) constructed an IPO portfolio to test with above models and found that IPO portfolio was underperforming which resulted significantly negative alpha during the period from 2000 to 2012.
} 
Roychoudhury (2014) found that IPOs with high initial liquidity underperform if they cannot sustain their high liquidity levels in long run. There are different dimensions of liquidity as proposed by different authors. Holden, Jacobson, and Subrahmanyam (2014) discussed three dimensions of liquidity which are cost, quantity and time. Alternatively, Saar and Lybek (2002) classified liquidity in to four types which are transaction cost, price, and volume and market impact. All those qualities of liquidity cannot be represented in a single measure. However, it is not the purpose of this paper to provide an extensive review on liquidity ${ }^{2}$. Amihud (2002) focussed on price based illiquidity and what is meant by illiquidity in this paper is also same as Amihud (2002). Amihud and Mendelson (1986) found a positive relation between illiquidity and stock returns. In other words, illiquid stocks provide higher returns compared to their liquid peers. One of the main purposes of this paper is to find out whether IPO long run stock price underperformance anomaly exists even after accounting for illiquidity based risk factors. For that purpose, authors of this paper have used two multi factor models. One is Carhart's (1997) four factor model which is the extension of Fama and French's (1993) three factor model by adding momentum as the fourth factor. Authors of this paper proposed a four factor model based on illiquidity of IPO stocks as the second model. Key difference between two models is Carhart's (1997) three factors except market risk premium are constructed based on firm size which is market capitalization of the firm. However, the factors of the proposed model are constructed on firm's illiquidity level but not the size. This leads to the second purpose of this paper. This paper aims to find out whether there is an additional explanatory power in illiquidity based four factor model than the conventional size based four factor model ${ }^{3}$. The rest of the paper is organized as follows. Section 2 discusses relevant literature and section 3 presents data and methodology. Section 4 analyzes the findings of the study and section 5 concludes.

\section{Literature Review}

This section of the paper presents relevant literature to the present paper and classifies them under three main areas namely IPO stock price underperformance, illiquidity in stock prices and asset pricing models.

\footnotetext{
${ }^{2}$ It can be referred to Kumar and Misra (2015); Holden, Jacobson and Subrahmanyam (2014) for that purpose.

${ }^{3}$ The terms "Carhart (1997) model" or "Conventional size based model" have been used interchangeably throughout the paper which authors are referring to the same model. Fama and French (1993); Carhart (1997) used size of the firm (measured by market capitalization) to construct SMB, HML and WML factors in their models. Rouwenhorst (1998); Liew and Vassalou (2000) followed this method to construct risk factors in international stock markets. That is the reason why authors have used the term "Conventional size based model" in this paper.
} 


\section{IPO Long Run Stock Price Underperformance}

As mentioned above, Ritter (1991) first observed and documented this anomaly. However, it is not a universal phenomenon like IPO underpricing which can be observed in almost all the markets in the world. But some evidence for IPO long run underperformance anomaly are provided by Levis (1993); Aggarwal, Leal and Hernandez (1993); Ljungqvist (1997); Kooli and Suret (2004); Zaluki, Campbell, and Goodacre (2007); Sahoo and Rajib (2010); Bossin and Sentis (2012). In Sri Lankan context, Peter (2007) analyzed on long run price performance of IPOs using buy and hold return technique under event study methodology. His results were Sri Lankan IPOs providing excess returns in first two years which is contradicted to the above findings of IPO long run underperformance. However $3^{\text {rd }}$ year returns after listing, turned negative and was in line with the IPO long run underperformance anomaly. Ediriwickrama and Azeez (2015) analyzed Sri Lankan IPO long run performance using multi factor models under calendar time approach and found IPO stock portfolio resulted significant negative returns. Further they found beta is significantly positive among Sri Lankan IPO stocks. It contradicts with the findings of Samarakoon (1997) where he found a negative relation between stock returns and beta after considering entire stock market of Sri Lanka. So it confirms that beta of IPO stocks behave differently than matured ordinary stocks.

\section{Illiquidity in Stock Prices}

Amihud and Mendelson (1986) published a seminal work which postulates the positive relationship between illiquidity and average stock returns. Many subsequent studies confirmed this result in many markets including Brennan and Subrahmanyam (1996); Datar, Naik and Radcliffe (1998); Chordia and Subrahmanyam (2001); Faff, Chai, and Gharghori (2013). However, some studies found inconsistent results and some of them are Marcelo, Quiros, and Oliveira (2011); Eleswarapu and Reinganum (1993). Amihud (2002) presented an illiquidity measure which is an average of absolute stock returns across stocks to dollar volume. Even though there are many measures of liquidity and illiquidity, many researchers including Lam and Tam (2011) prefer Amihud's measure since it can be computed using easily obtainable data. Acharya and Pederson (2005) developed a liquidity adjusted capital asset pricing model (LCAPM). They developed a concept called net beta and presented three additional betas in addition to standard market beta. They are, commonality in liquidity with market liquidity, return sensitivity to market liquidity and liquidity sensitivity to market return. Lee (2011) tested LCAPM model on global level. He found consistent results with the Acharya and Pederson's (2005) LCAPM model. However, liquidity risk premium is more prominent in large and developed markets. Situation in small and emerging markets is different and frequently produces marginal or low liquidity risk premiums according to Hearn and Piesse (2009) in African markets 
and Lischewski and Voronkova (2012) in Eastern Europe. Since Sri Lanka can also be categorized as a small and developing market, it is interesting to see whether liquidity premium is priced or not. Pastor and Stambaugh (2003) conducted another seminal study and found out that expected stock returns are related in cross section to the aggregate liquidity.

\section{Liquidity and Asset Pricing Models}

Ibbotson, Chen, Kim, and $\mathrm{Hu}$ (2013) stated that liquidity should be given an equal chance among other popular asset pricing factors such as size, book to market ratio (BTM) and momentum. Fama and French (1993) added two more risk factors to the CAPM to represent size (measured by market capitalization) and value (measured by book to market ratio). Size anomaly is that small companies can earn higher risk adjusted returns compared their large counterparts. Before Fama and French, Banz (1981) presented the empirical finding that smallest 20 per cent of firms earn an annual return that is almost 5 per cent higher than the return on other companies. Value anomaly is the tendency of value stocks (stocks with low prices relative to their fundamentals) to outperform growth stocks (stocks with high prices relative to fundamentals). Statman (1980) and Rosenberg (1985) performed statistical tests related to value factor before Fama and French combining value and size in their seminal paper in 1993. Carhart (1997) added fourth factor to three factor model which is short run momentum. Momentum is the continuation of stocks that have performed well recently to do well over the subsequent one to twelve months. On the contrary, long term reversals refer to the pattern of winner stocks (stocks did well in short term) tending become losers in the long run and vice versa. This is confirmed by DeBondt and Thaler (1985) well before the Carhart (1997) regarding long run momentum. They found that good performing stocks in short run become poor performers over three and five years and vice versa. Jegadeesh and Titman (1993) examined short run momentum and found out winner portfolio continues to outperform loser portfolio over the time horizons of three months to one year.

Lam and Tam (2011); Eckbo and Norli (2005) attempted to incorporate liquidity as an additional factor to the four factor model. Both studies produced significant coefficients indicating there was a positive liquidity premium. Eckbo and Norli (2005) are more important to the present study, since it compared IPO stock portfolios with seasoned equity offering (SEO) portfolios. When reviewing the literature it can be found that researchers attempting to adjust standard market beta to the liquidity like Acharya and Pederson (2005) model or adding liquidity as a new factor to the multi factor models like the study of Lam and Tam (2011). Factors in popular multi factor models such as Fama and French (1993); Carhart (1997) are constructed based on size except market risk premium. This method has been followed by Rouwenhorst (1998); Liew and Vassalou (2000) to test the asset pricing models in international markets. In this 
study authors attempted to replace firm size with illiquidity and compare the results using an IPO stock portfolio in emerging Sri Lankan market.

\section{Data and Methodology}

Sub section 3.1 describes on data used for the present study and 3.2 presents methodology followed in the study.

\section{Data}

The data used in this study consist of 60 IPOs listed in CSE from January 2003 to December 2015. The issue dates and offering prices of IPOs are taken from $\mathrm{CSE}^{4}$ and listing prospectuses. Monthly stock prices are taken from CSE and adjusted by authors to dividends and other corporate actions. All share price index (ASPI) data is obtained from CSE and considered as the market index. Factor data such as size, book to market ratio (BTM) and momentum (past returns) were mainly obtained from CSE and individual company annual reports. Risk free rate is taken as three month Treasury bill rate published by central bank of Sri Lanka (CBSL).

\section{Methodology}

Construction of IPO stock portfolio return. Single IPO firm daily portfolio return for month $m$ is calculated as follows. It is the monthly natural logarithm of single IPO firm return.

$$
R_{i m}=\ln \left[\frac{P_{i c p m}}{P_{i c p m-1}}\right]
$$

where $R_{i m}$ is the single IPO firm $i$ monthly return for month $m, P_{i c p m}$ is closing price of IPO firm for month $m$ and $P_{i c p m-1}$ is closing price of IPO firm for month $m$ - 1 . Equally weighted IPO portfolio return is calculated as follows.

$$
R_{\text {IPOMEW }}=1 / N \sum_{i=1}^{N} R_{i m}
$$

where $R_{I P O m E W}$ is the equally weighted return of IPO portfolio for month $m$ and $N$ is number of IPO stocks in the portfolio. Next step is to calculate value weighted IPO portfolio return. Weights were calculated according to $31^{\text {st }}$ December market capitalization of each firm. IPO companies

\footnotetext{
${ }^{4}$ Data is taken from CSE data library compact disc (CD) which was updated to quarter 4 of 2015.
} 
were included to construct IPO portfolio return from listing to five years or delisting where earlier of the two situations is taken. When there are missing prices (when there is no trading) for IPO firms, last traded price was taken to compute the return. Fama (1998) explained that equal weighted scenarios are poor approximations compared to value weighted scenarios in long run return evaluations. Value weighted IPO portfolio return is calculated as follows.

$R_{\text {IPOm } v w}=\sum_{i=1}^{N} W_{i y} R_{i m}$

where $R_{I P O m V W}$ is the value weighted return of IPO portfolio for month $m$ and $W_{i y}$ is the weight based on $31^{\text {st }}$ December market capitalization of IPO firms for each year $y$.

Amihud (2002) illiquidity measure. Amihud's (2002) illiquidity ratio is used as the main measurement of the illiquidity throughout this paper. It is adjusted to a monthly version to suit the Sri Lankan data since it is originally developed by Amihud (2002) for a year. It is calculated as follows.

$I L L I Q_{i m}=1 / D_{i m} \sum_{t=1}^{D i m}\left|R_{i m d}\right| / V O L R S_{i v m d}$

where, $I L L I Q_{i m}$ is monthly illiquidity measure of stock $i, D_{i m}$ is number of days per month $m$, $R_{i m d}$ is return on stock $i$ on day $d$ of month $m$ and VOLRS ${ }_{i v m d}$ is respective daily volume for month in Sri Lankan Rupees. This measure captures price shock triggered by one unit of Rs. Volume and can be classified as a price impact measure. Many researchers used this measure since it is easy to execute even though there are limitations. It doesn't capture important qualities of liquidity such as transaction costs and aggregate market impact.

Asset pricing models and their construction. Two asset pricing models are used in this paper and one is Carhart (1997) four factor model. That is shown in Equation 5.

$$
R_{I P O m}-R F_{m}=\alpha+\beta\left(R M_{m}-R F_{m}\right)+s S M B_{m}+h H M L_{m}+w W M L_{m}+\varepsilon_{m}
$$


where $R_{I P O m}$ is monthly return of the IPO stock portfolio ${ }^{5}, \mathrm{RM}$ is market rate of return, RF is risk free rate of return, SMB is average return difference between small and big stocks, HML is average return difference between high book to market ratio stocks and low book to market ratio stocks and WML is average return difference between past winner stocks and past loser stocks.

Other asset pricing model used in this study is proposed illiquidity based four factor model. In this model, SMB, HML and WML are replaced by SIZEILL, BTMILL and MOMILL respectively. However the only difference between these factors are that SMB, HML and WML are constructed based on firm size while SIZEILL, BTMILL and MOMILL are constructed based on illiquidity measured by Amihud (2002) illiquidity ratio. This model is shown as below.

$R_{I P O m}-R F_{m}=\alpha+\beta\left(R M_{m}-R F_{m}\right)+s S I Z E I L L_{m}+b B T M I L L_{m}+m M O M I L L_{m}+\varepsilon_{m}$

where, SIZEILL is size premium based on illiquidity, BTMILL is value premium based on illiquidity and MOMILL is momentum premium based on illiquidity while others are same as the Equation 5. Table 1 and Figure 1 show how to construct these new illiquidity based factors.

These two asset pricing models were regressed according to ordinary least square (OLS) method as well as weighted least square method (WLS). Under WLS, four weighting series will be allocated for each factor in respective asset pricing model. In addition, white heteroscedasticity consistent standard and covariance and Newey-West HAC standard errors and covariance has been used under WLS. Serial correlation of regression models were tested by Breusch-Godfrey serial correlation LM tests (BGSCLM) and heteroscedasticity was tested by Breusch-PaganGodfrey heteroscedasticity (BPGH) test.

Table 1 shows how to construct the factors. Three size based factors are SMB, HML and WML. SMB is the average return difference between small and big stocks. It is the return difference between three small portfolios which are SL, SM \& SH and three big portfolios which are BL, BM \& BH. HML is the average return difference between value and growth stocks. It is the return difference between two value portfolios which are SH \& BH and two growth portfolios which are SL \& BL. WML is the average return difference between past winner and past loser stocks. It is the return difference between two winner portfolios which are SW \& BW and two

${ }^{5} R_{I P O m}$ takes the form of equal weighted or value weighted depending on the respective calculation. It is subsequently expressed as EWRI (equal weighted return) or VWRI (value weighted return) throughout the paper. 
loser portfolios which are SL \& BL. Three illiquidity based factors are SIZEILL (size and illiquidity), BTMILL (book to market ratio and illiquidity) and MOMILL (momentum and illiquidity).

Table 1: Construction of Size and Illiquidity Based Portfolios

\begin{tabular}{llll}
\hline Type & Sort & Break points & Factors \& their construction \\
\hline Size & $2 * 3$ sorts on, & Size: Median & $(1) S M B=[(\mathrm{SL}+\mathrm{SM}+\mathrm{SH}) / 3]-[(\mathrm{BL}+\mathrm{BM}+\mathrm{BH}) / 3]$ \\
based & Size \& book to & BTM: $30^{\text {th }}$ and & $(2) \mathrm{HML}=[(\mathrm{SH}+\mathrm{BH}) / 2]-[(\mathrm{SL}+\mathrm{BL}) / 2]$ \\
factors & market ratio & $70^{\text {th }}$ percentile & $(3) \mathrm{WML}=[(\mathrm{SW}+\mathrm{BW}) / 2]-[(\mathrm{SL}+\mathrm{BL}) / 2]$ \\
& $\begin{array}{l}\text { BTM }) \\
\text { Size } \&\end{array}$ & $70^{\text {th }}$ percentile & \\
& momentum & & \\
& $(\mathrm{MOM})$ &
\end{tabular}

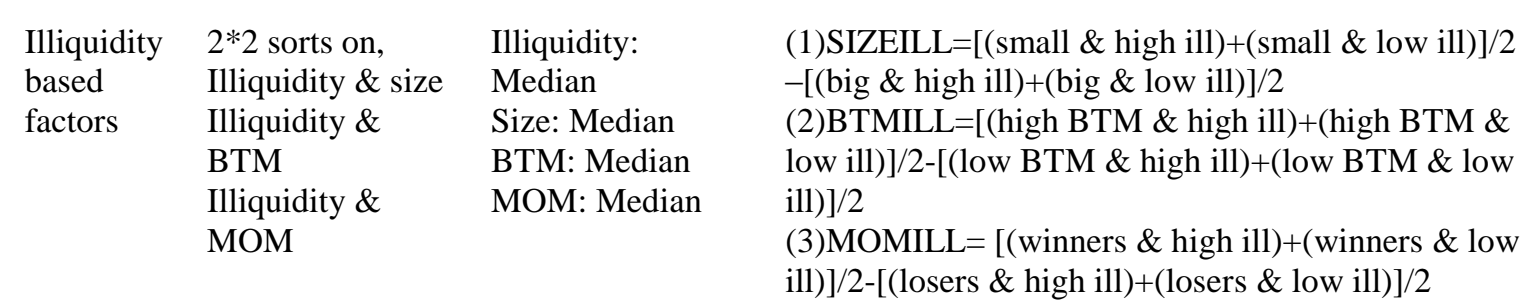

Source: Based on Fama and French (1993) and Carhart (1997)

SIZEILL can be interpreted as how much returns are associated with one unit of risk of this SIZEILL factor which was constructed based on the size and illiquidity. SIZEILL was constructed by forming a portfolio by going long small stocks and shorting big stocks. Similarly BTMILL can be interpreted as how much return are associated with one unit of risk of this BTMILL factor which was constructed based on book to market ratio and illiquidity. BTMILL was constructed by forming a portfolio by going long high book to market ratio stocks (value stocks) and shorting low book to market ratio stocks (growth stocks). MOMILL is also can be interpreted as how much returns are associated with one unit of risk of MOMILL factor which was constructed based on short run momentum and illiquidity. MOMILL was constructed by forming a portfolio by going long past winner stocks in short run and shorting past loser stocks in short run. 


\section{Figure 1: Construction of Illiquidity Based Risk Factors}

\section{Construction of SIZEILL (size and illiquidity) factor}

\begin{tabular}{lll} 
& \multicolumn{2}{c}{ Illiquidity } \\
Size & High illiquidity & Low illiquidity \\
Small & Small \& High ill & Small \& Low ill \\
Big & Big \& High ill & Big \& Low ill
\end{tabular}

Construction of BTMILL (book to market ratio and illiquidity) factor

$\begin{array}{cll}\text { Book to market ratio (BTM) } & \text { High illiquidity } & \text { Illiquidity } \\ \text { High } & \text { High BTM \& High ill } & \text { Low illiquidity } \\ \text { Low } & \text { Low BTM \& High ill } & \text { Low BTM \& Low ill } \\ & & \text { How ill }\end{array}$

Construction of MOMILL (momentum and illiquidity) factor

\begin{tabular}{clc} 
& \multicolumn{2}{c}{ Illiquidity } \\
Momentum & High illiquidity & Low illiquidity \\
Winners & Winners \& High ill & Winners \& Low ill \\
Losers & Losers \& High ill & Losers \& Low ill
\end{tabular}

Notes:

1. SIZEILL factor is constructed as follows: SIZEILL $=[($ small \& high ill $)+($ small \& low ill $)] / 2-[($ big \& high ill $)+($ big \& low ill)]/2

2. BTMILL factor is constructed as follows: BTMILL $=[($ high BTM \& high ill $)+($ high BTM \& low ill $)] / 2-[($ low BTM \& high ill $)+($ low BTM \& low ill $)] / 2$

3. MOMILL factor is constructed as follows: MOMILL= [(winners \& high ill) $+($ winners \& low ill $)] / 2-[($ losers \& high ill $)+($ loser \& low ill $)] / 2$

\section{Analysis}

\section{Descriptive Statistics}

Descriptive statistics of the variables are given in Table 2. Mean and median excess returns on IPO stock portfolio over risk free rate is negative irrespective of whether it is equally weighted or value weighted. The statistical range (difference between maximum and minimum) is also high for both equally weighted and value weighted IPO excess returns indicating the presence of extreme values in the data set. However authors did not attempt to winsorize or truncate the data set because it is already a small data set compared to similar studies. Value weighted returns resulted more standard deviation compared to equally weighted returns. Fama (1998) supports the use of value weighted returns since it represents total wealth effects. Mean and median market 
risk premium is negative for the study period from 2003 to 2015 . This means that investing in a risk free asset (for an example, three month Treasury bill) is profitable than investing in a risky asset like a stock. In other words, market risk premium has been reversed during the study period. Means and medians of SMB, HML and WML resulted marginal but positive returns except median SMB which resulted negative returns. So there is an inverted size effect when median SMB is considered. New illiquidity factors also present marginal but positive returns. Here SMB, HML and WML should be compared with SIZEILL, BTMILL, and MOMILL respectively. Mean values of SIZEILL and BTMILL exceed means of SMB and HML, but mean WML exceed mean MOMILL.

Table 2: Monthly Descriptive Statistics of Variables

\begin{tabular}{lrrrrrrrrr}
\hline & EWRI-RF & VWRI-RF & RM-RF & \multicolumn{1}{l}{ SMB } & HML & WML & SIZEILL & BTMILL & MOMILL \\
Mean & -0.096 & -0.101 & -0.086 & 0.002 & 0.011 & 0.014 & 0.004 & 0.015 & 0.009 \\
Median & -0.091 & -0.092 & -0.075 & -0.005 & 0.008 & 0.005 & 0.002 & 0.007 & 0.015 \\
Maximum & 0.161 & 0.293 & 0.141 & 0.249 & 0.275 & 0.371 & 0.235 & 0.314 & 0.188 \\
Minimum & -0.392 & -0.462 & -0.334 & -0.189 & -0.174 & -0.286 & -0.253 & -0.173 & -0.184 \\
Std. Dev. & 0.094 & 0.105 & 0.084 & 0.069 & 0.065 & 0.094 & 0.071 & 0.065 & 0.066 \\
Obs. & 156 & 156 & 156 & 156 & 156 & 156 & 156 & 156 & 156 \\
\hline
\end{tabular}

Note: Table 2 presents the time series averages of the monthly descriptive statistics. EWRI-RF is equal weighted excess IPO portfolio return over risk free rate, VWRI-RF is value weighted excess IPO portfolio return over risk free rate, RM-RF is market risk premium, SMB is size factor, HML is book to market ratio factor, WML is momentum factor, SIZEILL is size factor based on illiquidity, BTMILL is book to market ratio factor based on illiquidity and MOMILL is momentum factor based on illiquidity.

\section{Correlation Analysis}

Table 3 presents correlations between pairs of variables. Equally weighted excess IPO portfolio return (EWRI-RF) and value weighted excess IPO portfolio return (VWRI-RF) exhibits a good positive correlation with market risk premium (RM-RF) exceeding 80 per cent which is statistically significant. SMB's correlation with RM-RF, EWRI-RF and VWRI-RF is higher than proposed SIZEILL's correlations with those 3 variables. However proposed BTMILL's correlation with RM-RF, EWRI-RF and VWRI-RF is higher than conventional HML's correlations. MOMILL's correlations also exceed conventional WML correlations with RM-RF, EWRI-RF and VWRI-RF. Correlation between SMB and SIZEILL is healthy 91.3 per cent and correlation between HML and BTMILL is 58.1 per cent. Further correlation between WML and MOMILL is 79.5 per cent. This indicates that conventional risk factors of Carhart (1997) model and proposed illiquidity based risk factors are moving in to the same direction. 
Table 3: Correlations between Variables

\begin{tabular}{|c|c|c|c|c|c|c|c|c|c|}
\hline Variable & EWRI-RF & VWRI-RF & RM-RF & SMB & HML & WML & SIZEILL & BTMILL & MOMILL \\
\hline EWRI-RF & 1 & & & & & & & & \\
\hline VWRI-RF & $\begin{array}{r}0.836 \\
(0.000)\end{array}$ & 1 & & & & & & & \\
\hline RM-RF & $\begin{array}{r}0.841 \\
(0.000)\end{array}$ & $\begin{array}{r}0.829 \\
(0.000)\end{array}$ & 1 & & & & & & \\
\hline SMB & $\begin{array}{r}0.411 \\
(0.000)\end{array}$ & $\begin{array}{r}0.091 \\
(0.260)\end{array}$ & $\begin{array}{r}0.189 \\
(0.018)\end{array}$ & 1 & & & & & \\
\hline HML & $\begin{array}{r}-0.014 \\
(0.857)\end{array}$ & $\begin{array}{r}-0.071 \\
(0.382)\end{array}$ & $\begin{array}{r}0.027 \\
(0.739)\end{array}$ & $\begin{array}{c}-0.164 \\
(0.041)\end{array}$ & 1 & & & & \\
\hline WML & $\begin{array}{r}0.075 \\
(0.351)\end{array}$ & $\begin{array}{r}0.069 \\
(0.387)\end{array}$ & $\begin{array}{r}0.047 \\
(0.562)\end{array}$ & $\begin{array}{r}0.049 \\
(0.538)\end{array}$ & $\begin{array}{l}-0.112 \\
(0.163)\end{array}$ & 1 & & & \\
\hline SIZEILL & $\begin{array}{r}0.337 \\
(0.000)\end{array}$ & $\begin{array}{r}0.055 \\
(0.499)\end{array}$ & $\begin{array}{r}0.118 \\
(0.142)\end{array}$ & $\begin{array}{r}0.913 \\
(0.000)\end{array}$ & $\begin{array}{l}-0.112 \\
(0.164)\end{array}$ & $\begin{array}{r}0.091 \\
(0.262)\end{array}$ & 1 & & \\
\hline BTMILL & $\begin{array}{r}0.081 \\
(0.314)\end{array}$ & $\begin{array}{r}0.002 \\
(0.982)\end{array}$ & $\begin{array}{r}0.126 \\
(0.118)\end{array}$ & $\begin{array}{r}0.066 \\
(0.417)\end{array}$ & $\begin{array}{r}0.581 \\
(0.000)\end{array}$ & $\begin{array}{r}0.009 \\
(0.906)\end{array}$ & $\begin{array}{r}0.069 \\
(0.387)\end{array}$ & 1 & \\
\hline MOMILL & $\begin{array}{r}0.124 \\
(0.122) \\
\end{array}$ & $\begin{array}{r}0.115 \\
(0.152) \\
\end{array}$ & $\begin{array}{r}0.116 \\
(0.148) \\
\end{array}$ & $\begin{array}{r}0.023 \\
(0.777) \\
\end{array}$ & $\begin{array}{r}-0.039 \\
(0.632) \\
\end{array}$ & $\begin{array}{r}0.795 \\
(0.000) \\
\end{array}$ & $\begin{array}{r}0.075 \\
(0.351) \\
\end{array}$ & $\begin{array}{r}0.227 \\
(0.004) \\
\end{array}$ & 1 \\
\hline
\end{tabular}

Note: Table 3 presents the time series averages of the monthly time series correlations and $p$ values are reported in parentheses. EWRI-RF is equal weighted excess IPO portfolio return over risk free rate, $V W R I-R F$ is value weighted excess IPO portfolio return over risk free rate, RM-RF is market risk premium, SMB is size factor, HML is book to market ratio factor, WML is momentum factor, SIZEILL is size factor based on illiquidity, BTMILL is book to market ratio factor based on illiquidity and MOMILL is momentum factor based on illiquidity.

\section{Ordinary Least Square (OLS) Regression Analysis}

Carhart (1997) four factor asset pricing model and proposed illiquidity based four factor model were used for OLS regression analysis. Dependent variables for the analysis are EWRI-RF and VWRI-RF. Time period for the study is 156 months from January 2003 to December 2015. Further analysis is segregated to interwar period and post war period for better clarity. Inter war period covers from January 2003 to May 2009. Post war period covers from June 2009 to December 2015.

Table 4 reports OLS regression results for both asset pricing models. Significantly negative coefficient for constant is reported when EWRI-RF used as the dependent variable for full period and interwar period. But when VWRI-RFis used as the dependent variable, that negative significance of the constant is disappeared.Fama (1998) mentioned that usage of proper 
methodology will solve many long run return anomalies including IPOs. Disappearance of negative significance of constant when used value weighted returns can be interpreted as an good example to Fama (1998). However with both dependent variables and in all the time periods (full period, interwar period and post war period) as well as in both asset pricing models, coefficient of RM-RF is significantly positive for IPO stocks irrespective of the finding of Samarakoon (1997) for the entire Sri Lankan equity market which is negative relation between beta and stock returns. Coefficients of SMB and SIZEILL are significantly positive indicating there is a valid size premium when EWRI-RF is used. When VWRI-RF is used as dependent variable, size premium turns negative but not significant or marginally significant in many occasions. When EWRI-RF is used as the dependent variable, coefficients of both HML and BTMILL are not significant and when VWRI-RF is used they have shown an inverted significant value effect for full period and interwar period, but not for the post war period. Both coefficients of WML and MOMILL showed similar but inconsistent results across different time periods. Adjusted R squared for both models are above 65 per cent indicating that extent of the variation of IPO portfolio return explained by the OLS regression. F statistic is also highly significant for all the cases indicating all variables are jointly explaining the IPO stock portfolio return variation.

Table 4: Time Series Ordinary Least Square (OLS) Regression Results for the Period from January 2003 to December 2015

\begin{tabular}{|c|c|c|c|c|c|c|}
\hline \multirow[t]{2}{*}{$\begin{array}{l}\text { Dependent } \\
\text { variable }\end{array}$} & \multicolumn{3}{|c|}{$\begin{array}{c}\text { Excess IPO portfolio return on equal } \\
\text { weighted basis } \\
\text { (EWRI-RF) }\end{array}$} & \multicolumn{3}{|c|}{$\begin{array}{l}\text { Excess IPO portfolio return on value } \\
\text { weighted basis (VWRI-RF) }\end{array}$} \\
\hline & Full period & Inter war & Post war & Full period & Inter war & Post war \\
\hline \multicolumn{7}{|c|}{ Panel A: Conventional 4 factor model of Fama and French (1993) and Carhart (1997) } \\
\hline Constant & $\begin{array}{r}-0.022 * * * \\
(-4.044)\end{array}$ & $\begin{array}{r}-0.036^{* * *} \\
(-5.031)\end{array}$ & $\begin{array}{r}-0.000 \\
(-0.027)\end{array}$ & $\begin{array}{r}-0.007 \\
(-1.075)\end{array}$ & $\begin{array}{c}-0.018^{*} \\
(-1.746)\end{array}$ & $\begin{array}{r}0.003 \\
(0.339)\end{array}$ \\
\hline $\mathrm{RM}-\mathrm{RF}$ & $\begin{array}{r}0.881 * * * \\
(19.989)\end{array}$ & $\begin{array}{r}0.776 * * * \\
(16.028)\end{array}$ & $\begin{array}{r}1.136 * * * \\
(13.246)\end{array}$ & $\begin{array}{r}1.064 * * * \\
(18.787)\end{array}$ & $\begin{array}{r}0.984 * * * * \\
(14.373)\end{array}$ & $\begin{array}{r}1.161 * * * \\
(11.504)\end{array}$ \\
\hline SMB & $\begin{array}{r}0.351 * * * \\
(6.525)\end{array}$ & $\begin{array}{r}0.407 * * * \\
(6.589)\end{array}$ & $\begin{array}{r}0.193 * * \\
(2.234)\end{array}$ & $\begin{array}{l}-0.133^{*} \\
(-1.921)\end{array}$ & $\begin{array}{r}-0.113 \\
(-1.298)\end{array}$ & $\begin{array}{l}-0.196^{*} \\
(-1.923)\end{array}$ \\
\hline HML & $\begin{array}{r}0.014 \\
(0.251)\end{array}$ & $\begin{array}{r}-0.043 \\
(-0.609)\end{array}$ & $\begin{array}{r}-0.002 \\
(-0.025)\end{array}$ & $\begin{array}{r}-0.170 * * \\
(-2.328)\end{array}$ & $\begin{array}{r}-0.395 * * * \\
(-3.932)\end{array}$ & $\begin{array}{r}0.052 \\
(0.536)\end{array}$ \\
\hline WML & $\begin{array}{r}0.026 \\
(0.676)\end{array}$ & $\begin{array}{r}0.155^{* * *} * \\
(3.162)\end{array}$ & $\begin{array}{c}-0.103^{*} \\
(-1.910)\end{array}$ & $\begin{array}{r}0.025 \\
(0.507)\end{array}$ & $\begin{array}{r}0.172 * * \\
(2.489)\end{array}$ & $\begin{array}{c}-0.106^{*} \\
(-1.676)\end{array}$ \\
\hline $\begin{array}{l}\text { Adjusted R } \\
\text { squared }\end{array}$ & 0.768 & 0.823 & 0.751 & 0.697 & 0.756 & 0.656 \\
\hline F statistic & $129.049 * * *$ & $89.616 * * *$ & $59.785^{* * *}$ & $90.150 * * *$ & $60.012 * * *$ & $38.260 * * *$ \\
\hline Observations & 156 & 77 & 79 & 156 & 77 & 79 \\
\hline
\end{tabular}


Panel B: Proposed illiquidity based 4 factor model

\begin{tabular}{lrrrrrr}
\hline Constant & $-0.018 * * *$ & $-0.033 * * *$ & 0.002 & -0.007 & -0.016 & 0.004 \\
& $(-3.366)$ & $(-4.174)$ & $(0.211)$ & $(-1.070)$ & $(-1.426)$ & $(0.494)$ \\
RM-RF & $0.910 * * *$ & $0.805 * * *$ & $1.150 * * *$ & $1.058 * * *$ & $0.999 * * *$ & $1.186^{* * *}$ \\
& $(20.381)$ & $(15.322)$ & $(13.981)$ & $(18.673)$ & $(13.480)$ & $(12.071)$ \\
& & & & & & \\
SIZEILL & $0.320 * * *$ & $0.353 * * *$ & $0.167 * *$ & -0.060 & 0.003 & $-0.225 * *$ \\
factor & $(6.103)$ & $(5.433)$ & $(2.109)$ & $(-0.909)$ & $(0.030)$ & $(-2.370)$ \\
BTMILL & -0.062 & -0.098 & -0.036 & $-0.180 * *$ & $-0.273 * * *$ & -0.019 \\
factor & $(-1.060)$ & $(-1.446)$ & $(-0.343)$ & $(-2.438)$ & $(-2.858)$ & $(-0.152)$ \\
MOMILL & 0.030 & $0.203 * * *$ & $-0.187 * *$ & 0.073 & $0.260 * *$ & $-0.170 *$ \\
factor & $(0.516)$ & $(2.721)$ & $(-2.313)$ & $(0.994)$ & $(2.472)$ & $(-1.758)$ \\
Adjusted R & 0.761 & 0.798 & 0.758 & 0.695 & 0.723 & 0.656 \\
squared & & & & & & 772 \\
F statistic & $124.057 * * *$ & $76.172 * * *$ & $62.009 * * *$ & $89.217 * * *$ & $50.472 * * *$ & $38.127 * * *$ \\
Observations & 156 & 77 & 79 & 156 & 77 & 79 \\
\hline
\end{tabular}

Note: Panel A reports time series OLS regression results on conventional four factor model of Fama and French (1993) and Carhart (1997). Full period is 156 months from January 2003 to December 2015. Inter war period is 77 months from January 2003 to May 2009 and post war period is 79 months from June 2009 to December 2015. Two dependent variables were regressed which are excess IPO portfolio return (after deducting risk free rate which is 3 month treasury bill rate of Government of Sri Lanka) on both equal and value weighted basis (EWRI$R F$ and VWRI-RF). RM - RF represents market risk premium where $R M$ is the rate of return of all share price index (ASPI) of Colombo Stock Exchange (CSE) and RF is 3 month Treasury bill rate. SMB (small minus big) is the return difference between small and big stocks based on the market capitalization. HML (high minus low) is the return difference between high book to market ratio stocks (value stocks) and low book to market ratio stocks (growth stocks). WML (winner minus loser) is the return difference between past 12 month winner stocks and past 12 month loser stocks. Panel B reports time series OLS regression results on proposed illiquidity based four factor model. SIZEILL (size - illiquidity) factor is the average return difference between two small portfolios and two big portfolios based on illiquidity. BTMILL (book to market ratio - illiquidity) factor is the average return difference between two high book to market portfolios and two low book to market portfolios based on illiquidity. MOMILL (momentum - illiquidity) factor is the average return difference between two winner portfolios and two loser portfolios based on illiquidity. ***, **, * denote statistical significance at the 0.01, 0.05, 0.10 levels respectively and $t$ statistics are reported in parentheses.

Further OLS models were tested for serial correlation by Breusch Godfrey serial correlation LM test (BGSCLM) and heteroscedasticity by Breusch Pagan Godfrey heteroscedasticity test (BPGH). It is revealed that no serial correlation existed in OLS models discussed above. However BPGH test reveals that same OLS models are suffered from heteroscedasticity problem. As a solution to that, weighted least square (WLS) technique is used and it is discussed in the next section. 


\section{Weighted Least Square (WLS) Regression Analysis}

Table 5 reports WLS regression results. In this analysis four weighting series has been applied according to independent variables which are RM-RF, SMB, HML and WML for Carhart (1997) model and RM-RF, SIZEILL, BTMILL and MOMILL for proposed illiquidity based four factor model. In addition to that White heteroscedasticity consistent standard errors and covariance as well as Newey-West HAC standard errors and covariance have been used.

Panel A and B regression reports WLS regression results according to Carhart (1997) four factor model. Panel A reports regression results with dependent variable EWRI-RF and panel B presents regression results with dependent variable VWRI-RF. When EWRI-RF is used as the dependent variable, IPO stock portfolio is underperforming resulting negative significant coefficient of alpha except weighting series WML. However, when VWRI-RF is used as the dependent variable, WLS method generated marginally significant and inconsistent coefficient of alpha.As mentioned above in OLS analysis also, disappearance of negative significance of the constant is due to the value weighted returns used in the WLS analysis. So IPO underperformance is highly depended on the weighting scheme applied as noted by Fama (1998). Similar to OLS, WLS also generates highly significant positive beta coefficient for market risk premium irrespective of the dependent variable. When EWRI-RF is used, coefficient of SMB also has exhibited a significantly positive size effect. However, a completely different result is obtained for coefficient of SMB when dependent variable is VWRI-RF. Significantly negative size effect is reported for three weighting series which are RM-RF, SMB and WML. In other instances, coefficients of SMB are not significant. When VWRI-RF is used, coefficient of HML is negatively significant for three weighting series which are RM-RF, SMB and WML. However, when EWRI-RF is used, HML's coefficients exhibit inconsistent and marginally significant results. Coefficients of WML also result in inconsistent and marginally significant results for both EWRI-RF and VWRI-RF as well as for all the weighting series. Adjusted R squared is above than 73 per cent for EWRIRF and it is above than 63 per cent for VWRIRF when considered all the weighting series. F statistic is also highly significant for all regressions under Carhart (1997) four factor model.

Panels C and D reports WLS regression results according to proposed illiquidity based four factor model. Panel $\mathrm{C}$ reports regression results with dependent variable EWRI-RF and panel D presents regression results with dependent variable VWRI-RF. Similar to panels A and B of Table 5, IPO portfolio is underperforming in here also resulting negatively significant coefficient of alpha except for weighting series MOMILL when EWRI-RF is used as dependent variable. However with VWRI-RF, underperformance of IPO portfolio is marginally significant and inconsistent. Coefficient of RM-RF is positively significant similar to earlier results. When 
EWRI-RF is used as dependent variable, coefficient of SIZEILL is positively significant for all weighting series unlike with VWRI-RF where it produces inconsistent results across weighting series. Coefficient of BTMILL is significantly negative for weighting series SIZEILL and BTMILL with both EWRI-RF and VWRI-RF as dependent variables. Coefficient of MOMILL exhibits a positive momentum effect for weighting series SIZEILL and BTMILL with VWRI-RF as dependent variable. But with EWRI-RF, coefficient of MOMILL exhibits marginally significant and mixed results. Adjusted $\mathrm{R}$ squared for all the regressions under proposed illiquidity based four factor model is higher than 73 per cent for EWRI-RF and higher than 58 per cent for VWRI-RF. F statistics for all the regressions are highly significant indicating all factors of proposed illiquidity model are jointly explaining the return variation of IPO stock portfolio.

Table 5: Time Series Weighted Least Square (WLS) Regression Results for the Period from January 2003 to December 2015

\begin{tabular}{ccccccc}
\hline Weighting & WS & WS & WS & WS & White & $\begin{array}{c}\text { Newey- } \\
\text { West }\end{array}$ \\
series (WS) & RM-RF & SMB & HML & WML & & .
\end{tabular}

Panel A: Conventional 4 factor model of Fama and French (1993) and Carhart (1997) Dependent variable: Excess IPO portfolio returns on equal weighted basis (EWRI-RF)

\begin{tabular}{|c|c|c|c|c|c|c|}
\hline Constant & $\begin{array}{r}-0.029 * * * \\
(-3.682)\end{array}$ & $\begin{array}{r}-0.028 * * * \\
(-5.330)\end{array}$ & $\begin{array}{r}-0.018 * * * \\
(-3.027)\end{array}$ & $\begin{array}{r}0.001 \\
(0.176)\end{array}$ & $\begin{array}{r}-0.022 * * * \\
(-2.883)\end{array}$ & $\begin{array}{r}-0.022 * * * * \\
(-2.800)\end{array}$ \\
\hline RM-RF & $\begin{array}{r}0.873 * * * \\
(22.137)\end{array}$ & $\begin{array}{r}0.830 * * * \\
(20.705)\end{array}$ & $\begin{array}{r}0.926 * * * \\
(19.488)\end{array}$ & $\begin{array}{r}0.925 * * * \\
(18.277)\end{array}$ & $\begin{array}{r}0.881 * * * \\
(14.557)\end{array}$ & $\begin{array}{r}0.881 * * * \\
(14.436)\end{array}$ \\
\hline SMB & $\begin{array}{r}0.304 * * * * \\
(5.746)\end{array}$ & $\begin{array}{r}0.429 * * * \\
(16.662)\end{array}$ & $\begin{array}{r}0.475 * * * \\
(7.524)\end{array}$ & $\begin{array}{r}0.170 * * * * \\
(3.292)\end{array}$ & $\begin{array}{r}0.351 * * * * \\
(6.401)\end{array}$ & $\begin{array}{r}0.351 * * * \\
(7.177)\end{array}$ \\
\hline HML & $\begin{array}{r}-0.010 \\
(-0.175)\end{array}$ & $\begin{array}{r}-0.149 * * * \\
(-3.054)\end{array}$ & $\begin{array}{r}0.079 * * \\
(2.011)\end{array}$ & $\begin{array}{r}-0.038 \\
(-0.738)\end{array}$ & $\begin{array}{r}0.014 \\
(0.229)\end{array}$ & $\begin{array}{r}0.014 \\
(0.213)\end{array}$ \\
\hline WML & $\begin{array}{r}0.095 * * \\
(2.227)\end{array}$ & $\begin{array}{r}-0.015 \\
(-0.506)\end{array}$ & $\begin{array}{r}-0.035 \\
(-1.064)\end{array}$ & $\begin{array}{r}-0.018 \\
(-0.742)\end{array}$ & $\begin{array}{r}0.026 \\
(0.499)\end{array}$ & $\begin{array}{r}0.026 \\
(0.403)\end{array}$ \\
\hline $\begin{array}{l}\text { Adjusted R } \\
\text { squared }\end{array}$ & 0.786 & 0.873 & 0.802 & 0.734 & 0.768 & 0.768 \\
\hline F statistic & $142.933^{* * *}$ & $266.939 * * *$ & $158.337 * * *$ & $107.999 * * *$ & $129.049 * * *$ & $129.049 * * *$ \\
\hline Observations & 156 & 156 & 156 & 156 & 156 & 156 \\
\hline
\end{tabular}


Panel B: Conventional 4 factor model of Fama and French (1993) and Carhart (1997)

Dependent variable: Excess IPO portfolio returns on value weighted basis (VWRI-RF)

\begin{tabular}{|c|c|c|c|c|c|c|}
\hline Constant & $\begin{array}{r}-0.011 \\
(-1.052)\end{array}$ & $\begin{array}{r}-0.003 \\
(-0.380)\end{array}$ & $\begin{array}{r}-0.020 * * \\
(-2.318)\end{array}$ & $\begin{array}{r}0.039 * * * \\
(5.680)\end{array}$ & $\begin{array}{r}-0.007 \\
(-0.719)\end{array}$ & $\begin{array}{r}-0.007 \\
(-0.727)\end{array}$ \\
\hline RM-RF & $\begin{array}{r}1.053 * * * \\
(20.434)\end{array}$ & $\begin{array}{r}1.035^{* * * *} \\
(14.958)\end{array}$ & $\begin{array}{r}1.075^{* * *} * \\
(15.146)\end{array}$ & $\begin{array}{r}1.279 * * * \\
(22.069)\end{array}$ & $\begin{array}{r}1.064 * * * \\
(12.303)\end{array}$ & $\begin{array}{r}1.064 * * * \\
(11.684)\end{array}$ \\
\hline SMB & $\begin{array}{r}-0.235^{* * *} \\
(-3.408)\end{array}$ & $\begin{array}{r}-0.149 * * * \\
(-3.353)\end{array}$ & $\begin{array}{r}0.141 \\
(1.495)\end{array}$ & $\begin{array}{r}-0.460 * * * \\
(-7.768)\end{array}$ & $\begin{array}{r}-0.133 \\
(-1.413)\end{array}$ & $\begin{array}{r}-0.133 \\
(-1.401)\end{array}$ \\
\hline HML & $\begin{array}{r}-0.237 * * * \\
(-3.195)\end{array}$ & $\begin{array}{r}-0.288 * * * \\
(-3.416)\end{array}$ & $\begin{array}{r}-0.017 \\
(-0.293)\end{array}$ & $\begin{array}{r}-0.283 * * * \\
(-4.772)\end{array}$ & $\begin{array}{c}-0.170^{*} \\
(-1.819)\end{array}$ & $\begin{array}{c}-0.170 * \\
(-1.701)\end{array}$ \\
\hline WML & $\begin{array}{r}-0.032 \\
(-0.567)\end{array}$ & $\begin{array}{r}0.107 * * \\
(2.032)\end{array}$ & $\begin{array}{r}-0.071 \\
(-1.429)\end{array}$ & $\begin{array}{r}-0.027 \\
(-0.946)\end{array}$ & $\begin{array}{r}0.025 \\
(0.390)\end{array}$ & $\begin{array}{r}0.025 \\
(0.341)\end{array}$ \\
\hline $\begin{array}{l}\text { Adjusted R } \\
\text { squared }\end{array}$ & 0.735 & 0.630 & 0.674 & 0.765 & 0.697 & 0.697 \\
\hline F statistic & $108.292 * * *$ & $66.930 * * *$ & $81.126 * * *$ & $127.412 * * *$ & $90.150 * * *$ & $90.150 * * *$ \\
\hline Observations & 156 & 156 & 156 & 156 & 156 & 156 \\
\hline
\end{tabular}

Panel C: proposed illiquidity based 4 factor model

Dependent variable: Excess IPO portfolio returns on equal weighted basis (EWRI-RF)

\begin{tabular}{|c|c|c|c|c|c|c|}
\hline Constant & $\begin{array}{r}-0.028 * * * \\
(-3.601)\end{array}$ & $\begin{array}{r}-0.025 * * * \\
(-4.225)\end{array}$ & $\begin{array}{r}-0.018 * * * \\
(-2.792)\end{array}$ & $\begin{array}{r}-0.007 \\
(-1.076)\end{array}$ & $\begin{array}{r}-0.018 * * \\
(-2.465)\end{array}$ & $\begin{array}{r}-0.018 * * \\
(-2.300)\end{array}$ \\
\hline RM-RF & $\begin{array}{r}0.904 * * * \\
(23.468)\end{array}$ & $\begin{array}{r}0.858 * * * \\
(17.375)\end{array}$ & $\begin{array}{r}0.880^{* * *} \\
(18.391)\end{array}$ & $\begin{array}{r}0.943^{* * *} \\
(17.979)\end{array}$ & $\begin{array}{r}0.910 * * * \\
(14.986)\end{array}$ & $\begin{array}{r}0.910 * * * \\
(13.872)\end{array}$ \\
\hline $\begin{array}{l}\text { SIZE ILL } \\
\text { factor }\end{array}$ & $\begin{array}{r}0.222 * * * \\
(3.989)\end{array}$ & $\begin{array}{r}0.387 * * * \\
(13.902)\end{array}$ & $\begin{array}{r}0.383 * * * \\
(11.086)\end{array}$ & $\begin{array}{r}0.282^{* * * *} \\
(6.348)\end{array}$ & $\begin{array}{r}0.320 * * * \\
(5.415)\end{array}$ & $\begin{array}{r}0.320 * * * * \\
(5.347)\end{array}$ \\
\hline $\begin{array}{l}\text { BTM ILL } \\
\text { factor }\end{array}$ & $\begin{array}{r}0.098 \\
(1.506)\end{array}$ & $\begin{array}{r}-0.104 * * * \\
(-2.694)\end{array}$ & $\begin{array}{r}-0.155^{* * * *} \\
(-4.423)\end{array}$ & $\begin{array}{r}-0.019 \\
(-0.369)\end{array}$ & $\begin{array}{r}-0.062 \\
(-0.864)\end{array}$ & $\begin{array}{r}-0.062 \\
(-0.829)\end{array}$ \\
\hline $\begin{array}{l}\text { MOM ILL } \\
\text { factor }\end{array}$ & $\begin{array}{l}0.118^{*} \\
(1.944)\end{array}$ & $\begin{array}{r}0.066 \\
(1.426)\end{array}$ & $\begin{array}{r}0.111 * * \\
(2.225)\end{array}$ & $\begin{array}{r}-0.025 \\
(-0.544)\end{array}$ & $\begin{array}{r}0.030 \\
(0.386)\end{array}$ & $\begin{array}{r}0.030 \\
(0.308)\end{array}$ \\
\hline $\begin{array}{l}\text { Adjusted R } \\
\text { squared }\end{array}$ & 0.789 & 0.804 & 0.783 & 0.732 & 0.761 & 0.761 \\
\hline F statistic & $146.328 * * *$ & $160.208 * * *$ & $140.702 * * *$ & $107.032 * * *$ & $124.057 * * *$ & $124.057 * * *$ \\
\hline Observations & 156 & 156 & 156 & 156 & 156 & 156 \\
\hline
\end{tabular}


Panel D: proposed illiquidity based 4 factor model

Dependent variable: Excess IPO portfolio returns on value weighted basis (VWRI-RF)

\begin{tabular}{|c|c|c|c|c|c|c|}
\hline Constant & $\begin{array}{l}-0.018 * \\
(-1.675)\end{array}$ & $\begin{array}{r}-0.013 \\
(-1.460)\end{array}$ & $\begin{array}{r}-0.022 * * \\
(-2.546)\end{array}$ & $\begin{array}{r}0.021 * * * \\
(3.256)\end{array}$ & $\begin{array}{r}-0.007 \\
(-0.793)\end{array}$ & $\begin{array}{r}-0.007 \\
(-0.830)\end{array}$ \\
\hline RM-RF & $\begin{array}{r}1.021 * * * \\
(19.271)\end{array}$ & $\begin{array}{r}0.933 * * * \\
(12.542)\end{array}$ & $\begin{array}{r}0.845^{* * * *} \\
(12.997)\end{array}$ & $\begin{array}{r}1.174 * * * \\
(21.003)\end{array}$ & $\begin{array}{r}1.058 * * * \\
(12.855)\end{array}$ & $\begin{array}{r}1.058 * * * \\
(12.983)\end{array}$ \\
\hline $\begin{array}{l}\text { SIZE ILL } \\
\text { factor }\end{array}$ & $\begin{array}{r}-0.176^{* *} \\
(-2.302)\end{array}$ & $\begin{array}{r}0.024 \\
(0.573)\end{array}$ & $\begin{array}{r}0.223 * * * \\
\quad(4.758)\end{array}$ & $\begin{array}{r}-0.228 * * * \\
(-4.819)\end{array}$ & $\begin{array}{r}-0.060 \\
(-0.576)\end{array}$ & $\begin{array}{r}-0.060 \\
(-0.558)\end{array}$ \\
\hline $\begin{array}{l}\text { BTM ILL } \\
\text { factor }\end{array}$ & $\begin{array}{r}-0.020 \\
(-0.226)\end{array}$ & $\begin{array}{r}-0.450 * * * \\
(-7.717)\end{array}$ & $\begin{array}{r}-0.337 * * * \\
(-7.060)\end{array}$ & $\begin{array}{r}-0.022 \\
(-0.405)\end{array}$ & $\begin{array}{r}-0.180 \\
(-1.417)\end{array}$ & $\begin{array}{r}-0.180 \\
(-1.445)\end{array}$ \\
\hline $\begin{array}{l}\text { MOM ILL } \\
\text { factor }\end{array}$ & $\begin{array}{r}-0.030 \\
(-0.359)\end{array}$ & $\begin{array}{r}0.411 * * * \\
(5.855)\end{array}$ & $\begin{array}{r}0.278 * * * \\
\quad(4.101)\end{array}$ & $\begin{array}{r}0.002 \\
(0.047)\end{array}$ & $\begin{array}{r}0.073 \\
(0.790)\end{array}$ & $\begin{array}{r}0.073 \\
(0.727)\end{array}$ \\
\hline $\begin{array}{l}\text { Adjusted R } \\
\text { squared }\end{array}$ & 0.711 & 0.588 & 0.636 & 0.752 & 0.695 & 0.695 \\
\hline F statistic & $96.466 * * *$ & $56.245^{* * *}$ & $68.847 * * *$ & $118.466 * * *$ & $89.217 * * *$ & $89.217 * * *$ \\
\hline Observations & 156 & 156 & 156 & 156 & 156 & 156 \\
\hline
\end{tabular}

Note: Panel A and B report time series WLS regression results on conventional four factor model of Fama and French (1993) and Carhart (1997). Full period is 156 months from January 2003 to December 2015. Two dependent variables were regressed which are excess IPO portfolio return (after deducting risk free rate which is 3 month treasury bill rate of Government of Sri Lanka) on both equal and value weighted basis (EWRI-RF and VWRI$R F)$. There are four weighting series which are RM - RF, SMB, HML and WML in WLS methodology followed. Further White is referred to White Heteroscedasticity consistent standard errors and covariance. Newey-West is referred to Newey-West HAC standard errors and covariance. RM-RF represents market risk premium where $R M$ is the rate of return of all share price index (ASPI) of Colombo Stock Exchange (CSE) and RF is 3 month Treasury bill rate. SMB (small minus big) is the return difference between small and big stocks based on the market capitalization. HML (high minus low) is the return difference between high book to market ratio stocks (value stocks) and low book to market ratio stocks (growth stocks). WML (winner minus loser) is the return difference between past 12 month winner stocks and past 12 month loser stocks. Panel $C$ and D report time series WLS regression results on proposed illiquidity based four factor model. There are four weighting series which are RM-RF, SIZEILL, BTMILL and MOMILL in addition to White and Newey-West. SIZEILL (size illiquidity) factor is the average return difference between two small portfolios and two big portfolios based on illiquidity. BTMILL (book to market ratio - illiquidity) factor is the average return difference between two high book to market portfolios and two low book to market portfolios based on illiquidity. MOMILL (momentum illiquidity) factor is the average return difference between two winner portfolios and two loser portfolios based on illiquidity. $* * *, * *, *$ denote statistical significance at the 0.01, 0.05, 0.10 levels respectively and $t$ statistics are reported in parentheses.

\section{Conclusion}

There are two main purposes of this study. One is to find out whether IPO long run stock price underperformance anomaly exists whether even after pricing for the illiquidity premium.It is true that there is no additional illiquidity factor in the proposed model like Lam and Tam 
(2011). However illiquidity measured using Amihud's (2002) measure has been used to construct factors in the proposed model (SIZEILL, BTMILL and MOMILL). So this paper's argument is that hence illiquidity is incorporated to factors in their construction, there is no need to include a separate illiquidity factor. When EWRI-RF is used as the dependent variable, IPO stock portfolio underperformed in proposed illiquidity based four factor model for a full period and interwar period. This means that IPO long run stock price underperformance prevails even after pricing for the illiquidity. Second purpose of this paper is to find out whether proposed illiquidity based four factor model provides better explanatory power than the Carhart (1997) four factor model. In here, it should be emphasized that SMB, HML and WML are replaced by SIZEILL, BTMILL and MOMILL respectively. It should be noted that coefficients of factors in proposed illiquidity model (SIZEILL, BTMILL and MOMILL) behaved in very similar fashion to the coefficients of Carhart (1997) model factors (SMB, HML and WML). Further, adjusted R squared and F statistics are very high and significant for both the models. So it can be concluded that both models have performed very similarly and provided almost equal explanatory power. Further it is not fair to say that one model is better than other and vice versa. In addition to them, there are few more interesting findings. IPO stock portfolio significantly underperformed only in full period and inter war period and not in the post war period when considered with equal weighted returns. However, statistically significant underperformance cannot be observed with value weighted returns. This highlights the fact that Fama (1998) noted as proper methodology solves many long run return anomalies. Further standard market beta was positively significant in all the models and for all the periods. This finding related to IPO stocks is contradicted with general Sri Lankan equity market finding of Samarakoon (1997) which states beta is negatively significant. Only coefficients of SMB and SIZEILL were positively significant when considering the full period and coefficients of other factors are not significant (HML and BTMILL as well as WML and MOMILL). This indicates that newly added factors to the capital asset pricing model perform differently in different markets. For an example, Fama and French's (1993) three factor model which was highly successful in United States of America, was rejected in Japan by the study conducted by Daniel, Titman and Wei (2001).

There are limitations and further research opportunities arising from this study. This study considered only IPO stocks for 13 years in small and developing markets of Sri Lanka. Authors of this paper firmly believe that proposed illiquidity based four factor model should be tested in larger and developed markets such as USA, Japan etc Further it should be tested for all the stocks not only IPO stocks as in this paper. This study used only Amihud (2002) measure to represent illiquidity. But there are numerous measures to represent liquidity and illiquidity. So as a further research opportunity, proposed illiquidity based four factor model should be tested based on other liquidity measures as well. Further market risk premium is unchanged in proposed model. 
However, Acharya and Pederson (2005) developed LCAPM and now there is a possibility to link LCAPM and proposed illiquidity based factors (SIZEILL, BTMILL and MOMILL). Such type of a combined model may give more robust results in future research. There are several useful implications from this study to investors, policy makers, professionals and academic community. Investors can be more critical in their investment decisions on IPOs based on the outcomes of the study while policy makers can use findings of this research in setting up rules and regulations on IPOs. Professionals like financial analysts and portfolio managers will be able to think twice in recommending IPOs to their clients in the long run. Finally academics can use above mentioned further research opportunities to explore in areas of corporate finance and asset pricing.

\section{References}

Acharya, V. V., \& Pederson, L. H. (2005). Asset pricing with liquidity risk. Journal of Financial Economics, 77, 375-410.

Aggarwal, R., Leal, R., \& Hernandez, L. (1993). The aftermarket performance of initial public offerings in Latin America. Financial Management, 22(1), 42-53.

Amihud, Y. (2002). Illiquidity and stock returns: Cross section and time series effects. Journal of Financial Markets. 5(1), 31-56.

Amihud, Y., \& Mendelson, H. (1986). Asset pricing and the bid ask spread. Journal of Financial Economics. 17, 223-249.

Banz, R. (1981). The relationship between return and market value of common stocks. Journal of Financial Economics, 9, 3-18.

Bossin, R., \& Sentis, P. (2012). Long run performance of IPOs and the role of financial analysts: Some French evidence. The European Journal of Finance, 1-25.

Brennan, M. J., \& Subrahmanyam, A. (1996). Market microstructure and asset pricing: On the compensation for liquidity in stock returns. Journal of Financial Economics, 41, 441-464.

Carhart, M. M. (1997). On persistence in mutual fund performance. The Journal of Finance, 52, 57-82.

Chordia, T., \& Subrahmanyam, A. (2001). Trading activity and expected stock returns. Journal of Financial Economics, 59, 3-32.

Daniel, K., Titman, S., \& Wei, K. C. J. (2001). Explaining the cross section of stock returns in Japan: Factors or characteristics? The Journal of Finance, 56(2), 743-766.

Datar, V., Naik, N., \& Radcliffe, R. (1998). Liquidity and stock returns: An alternative test. Journal of Financial Markets, 1, 203-219.

Dayaratne, D. A. I. (2014). A comparative study of pre and post war performance of Colombo Stock Exchange (CSE). Sabaragamuwa University Journal, 13(1), 43-55. 
DeBondt, W., \& Thaler, R. (1985). Does the stock market overreact? The Journal of Finance, 40, 793-805.

Eckbo, B. E., \& Norli, O. (2005). Liquidity risk, leverage and long run IPO returns. Journal of Corporate Finance, 11(1\&2), 1-35.

Ediriwickrama, T. C., \& Azeez, A. A. (2015). Multi factor explanation to IPO long run underperformance anomaly: Sri Lankan evidence. The International journal of Accounting and Business Society, 23(2), 17-32.

Eleswarapu, V. R. \& Reinganum, M. R. (1993). The seasonal behaviour of liquidity premium in asset pricing. Journal of Financial Economics, 34, 373-386.

Faff, R., Chai, D., \& Gharghori, P. (2013). Liquidity and asset pricing: New Australian evidence using low frequency data. Australian Journal of Management, 38(2), 375-400.

Fama, E. F. (1998). Market efficiency, long term returns and behavioural finance. Journal of Financial Economics, 49, 283-306.

Fama, E. F., \& French, K. R. (1993). Common risk factors in stock and bond returns. The Journal of Finance, 33, 3-56.

Hearn, B., \& Piesse, J. (2009). An augmented capital asset pricing model: Liquidity and stock size in African emerging financial markets. African Journal of Finance, 27-57.

Holden, C.W., Jacobson, S., \& Subrahmanyam, A. (2014). The empirical analysis of liquidity. Foundations and Trends in Finance, 8(4), 263-365.

Ibbotson, R. G., Chen, Z., Kim, D. Y. J., \& Hu, W.Y. (2013). Liquidity as an investment style. Financial Analysts Journal. 69(3), 30-44.

Jegadeesh, N., \& Titman, S. (1993). Returns to buying winners and selling losers: Implications for stock market efficiency. The Journal of Finance, 48(1), 65-91.

Kooli, M., \& Suret, J. (2004). The aftermarket performance in initial public offerings in Canada. Journal of Multinational Financial Management, 14, 47-66.

Kumar, G., \& Misra, A. K. (2015). Closer view at the stock market liquidity: A literature review. Asian Journal of Finance and Accounting, 7(2), 35-57.

Lam, K. S. K., \& Tam, L. H. K. (2011). Liquidity and asset pricing: Evidence from the Hong Kong stock market. Journal of Banking and Finance, 35(9), 2217-2230.

Lee, K. (2011). The world price of liquidity risk. Journal of Financial Economics, 99, 136-161.

Levine, R., \& Zervos, S. (1996). Stock market development and long run growth. The World Bank Economic Review, 10(2), 323-339.

Levis, M. (1993). The long run performance of initial public offerings: The UK experience 19801988. Financial Management, 22(1), 28-41.

Liew, J., \& Vassalou, M. (2000). Can book to market, size and momentum be risk factors that predict economic growth? Journal of Financial Economics, 57, 221-245. 
Lischewski, J., \&Voronkova, S. (2012). Size, value and liquidity. Do they really matter on an emerging stock market? Emerging Markets Review, 13(1), 8-25.

Ljungqvist, A. (1997). The pricing of initial public offerings: Further evidence from Germany. European Economic Review, 41, 1309-1320.

Marcelo, J. L. M., Quiros, M. D. M. M., \& Oliveira, C. (2011). Asset pricing and liquidity: Evidence from Portugal. Retrieved April 26, 2015 from http://repositorio.ipl.pt/bitstream/ 10400.21/1427/1/31.pdf.

Pagano, M. (1993). Financial markets and growth: An overview. European Economic Review, $37(2), 613-622$.

Pastor, L., \& Stambaugh, R. F. (2003). Liquidity risk and expected stock returns. Journal of Political Economy, 111, 642-685.

Peter, S. (2007). Performance of initial public offerings and privatized offers: Evidence from a developing country. Managerial Finance, 33(10), 798-809.

Ritter, J. R. (1991). The long run performance of initial public offerings. The Journal of Finance, 46(1), 3-27.

Rosenberg, B. (1985). Prediction of common stock betas. Journal of Portfolio Management, 11, 5-14.

Rouwenhorst, K. G. (1998). International momentum strategies. The Journal of Finance, 53, 267-284.

Roychoudhury, S. (2014). Liquidity and IPO performance in the last decade. MITS International Journal of Business Research, 1(1), 1-10.

Saar, A., \& Lybek, T. (2002). Measuring liquidity in financial markets. (IMF Working Paper WP/02/23)

Sahoo, S., \& Rajib, P. (2010). Aftermarket pricing performance of initial public offerings: Indian IPO market 2002-2006. Vikalpa, 35(4), 27-43.

Samarakoon, L. P. (1997). The cross section of expected stock returns in Sri Lanka. Sri Lankan Journal of Management, 2(3), 234-250.

Schulz, M., \& Peiris, P. (2010). Reconstruction challenges in Sri Lanka. In: D. Herath, K. Hoglund, M. Schulz, \& K. T. Silva (Eds.), Post-war reconstruction in Sri Lanka: Prospects and challenges (pp. 17-48). Kandy, Sri Lanka: International Centre for Ethnic Studies.

Statman, D. (1980). Book values and stock returns. The Chicago MBA: A Journal of Selected Papers, 4, 25-45.

Zaluki, N. A., Campbell, K., \& Goodacre, A. (2007). The long run share price performance of Malaysian initial public offerings. Journal of Business, Finance and Accounting, 34(1), 78110. 